\title{
Fragmentation of Deprotonated N-Benzoylpeptides: Formation of Deprotonated Oxazolones
}

\author{
Alex G. Harrison and Alex B. Young \\ Department of Chemistry, University of Toronto, Toronto, Ontario, Canada
}

The fragmentation reactions of deprotonated N-benzoyl peptides, specifically hippurylglycine, hippurylglyclyclycine, and hippurylphenylalanine (hippuryl $=\mathrm{N}$-benzoylGly) have been studied using $\mathrm{MS}^{2}$ and $\mathrm{MS}^{3}$ experiments as well as deuterium labeling. A major fragment ion is observed at $\mathrm{m} / \mathrm{z} 160\left(\left[\mathrm{C}_{9} \mathrm{H}_{6} \mathrm{NO}_{2}\right]^{-}\right)$which, upon collisional activation, mainly eliminates $\mathrm{CO}_{2}$ indicating that the two oxygen atoms have become bonded to the same carbon. This observation is rationalized in terms of formation of deprotonated 2-phenyl-5-oxazolone. Various pathways to the deprotonated oxazolone have been elucidated through $\mathrm{MS}^{3}$ experiments. Fragmentation of deprotonated $\mathrm{N}$-acetylalanylalanine gives a relatively weak signal at $\mathrm{m} / \mathrm{z} 112$ which, upon collisional activation, fragments, in part, by loss of $\mathrm{CO}_{2}$ leading to the conclusion that the $m / z 112$ ion is deprotonated 2,4-dimethyl-5-oxazolone. (J Am Soc Mass Spectrom 2004, 15, 446-456) (C) 2004 American Society for Mass Spectrometry

$\mathrm{A}$ common fragmentation reaction of collisionally activated protonated peptides involves cleavage of an amide bond [1-4]. When the charge resides on the $\mathrm{C}$-terminal fragment a protonated amino acid $\left(\mathrm{y}_{1}{ }^{\prime \prime}\right)$ or smaller protonated peptide $\left(\mathrm{y}_{\mathrm{n}}{ }^{\prime \prime}\right)$ ion is formed $[5,6]$. When the charge resides on the $\mathrm{N}$ terminal fragment the $b$ ions formed, rather than having the expected acylium ion structure, have, in many cases, cyclized to form a protonated oxazolone [7-12]. Recent work by O'Hair and co-workers [13] suggests that in some cases alternative cyclic structures may be more stable than the oxazolone structure and thus, may be preferentially formed. Formation of oxazolone structures also rationalizes the observation that, while $b_{1}$ ions rarely are formed by cleavage of the first amide bond, N-acylation of the peptide frequently leads to cleavage of the $\mathrm{N}$-terminal peptide amide bond since stable oxazolones can be formed $[7,9,14]$.

Nominal amide bond cleavage also occurs for deprotonated peptides, as illustrated in Scheme 1, where the $\mathrm{y}_{\mathrm{n}}$ ions are deprotonated amino acids $\left(\mathrm{y}_{1}\right)$ or peptides $\left(\mathrm{y}_{\mathrm{n}}\right)$ and the $\mathrm{b}_{\mathrm{n}}$ ions bear two fewer hydrogens than the corresponding $b_{n}$ ions formed from protonated peptides. Formation of " $b_{n}$ ions was first noted by Heerma and co-workers [15, 16] and elaborated upon by Bowie and co-workers [17-19]. The latter authors proposed the mechanism outlined in Scheme 2 for formation of $" \mathrm{~b}_{2}$ ions, designating the pathway leading to the deprotonated amino acid as $\alpha$-cleavage and that

Published online February 1, 2004

Address reprint requests to Dr. A. G. Harrison, Department of Chemistry, University of Toronto, 80 St. George Street, Toronto, Ontario M5S 3H6, Canada. E-mail: aharriso@chem.utoronto.ca leading to the charged $\mathrm{N}$-terminal fragment as $\beta$-cleavage. From a low-energy CID study of deprotonated tripeptides, Harrison [20] proposed a similar direct cleavage of the amide bond but suggested that the charged N-terminal fragment had cyclized to form a deprotonated oxazolone. More recent studies [21] have shown that a major pathway to $" \mathrm{~b}_{2}$ ions from deprotonated tripeptides involves loss of a neutral amine from the $\mathrm{a}_{3}\left(\left[\mathrm{M}-\mathrm{H}-\mathrm{CO}_{2}\right]^{-}\right)$ion, as illustrated in Scheme 3, where again it is proposed that the " $b_{2}$ ion is a deprotonated oxazolone. The initial proton transfer reaction in Scheme 3 (and in later schemes) is undoubtedly exothermic but most likely involves a rotational barrier similar to the rotational barriers observed [22] in the fragmentation of $\mathrm{a}_{2}$ ions derived from deprotonated dipeptides. Recent ab initio calculations in this laboratory [23] show that the " $b_{2}$ ion structure proposed in Scheme 2 readily rearranges over low energy rotational barriers to form the deprotonated oxazolone of Scheme 3 , a cyclization which is ca. $23 \mathrm{kcal} \mathrm{mol}^{-1}$ exothermic. However, a N-deprotonated diketopiperazine is ca. 10 kcal $\mathrm{mol}^{-1}$ more stable than the deprotonated oxazolone. In the present work we report a study of the fragmentation reactions of deprotonated N-benzoylpeptides using $\mathrm{MS}^{2}$ and $\mathrm{MS}^{3}$ collision-induced dissociation (CID) studies as well as isotopic labeling. The results provide compelling evidence for formation of deprotonated oxazolones.

\section{Experimental}

Initial CID studies were carried out using an electrospray/quadrupole mass spectrometer (VG Platform, Micromass, Manchester, UK) with CID in the interface 


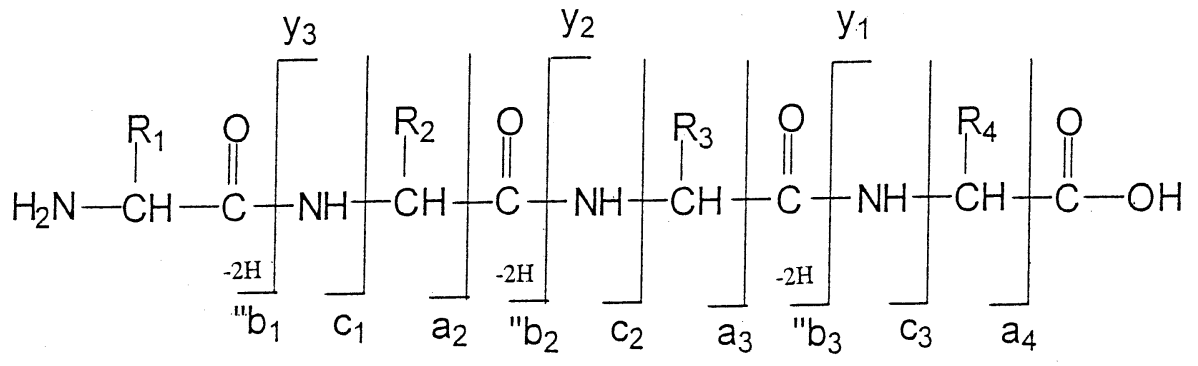

Scheme 1

region between the atmospheric pressure source and the quadrupole mass analyzer. It is well-known [24, 25] that CID can be achieved in this region, so-called cone-voltage CID, and it has been clearly established [26-28] that the average energy imparted to the decomposing ions increases as the field in the interface region increases. Recent studies [29-32] have shown that, by varying this field in steps, energy-resolved mass spectra [33] similar to those obtained by variable low-energy CID in quadrupole cells can be obtained. The results of these cone-voltage CID experiments are presented in the following as CID mass spectra at a set cone voltage. $\mathrm{MS}^{2}$ and $\mathrm{MS}^{3}$ experiments also were carried out using an electrospray/quadrupole/time-of-flight (QqTOF) mass spectrometer (QStar, MDS SCIEX, Concord, Can-<smiles>[R8]C(N)C(=O)NC([R3])C(=O)NC([R8])C(=O)[O-]</smiles><smiles>[R3]C(NC(=O)C([R6])NC(=O)C(N)Br)C(=O)O</smiles><smiles>[R3]C(N)C(=O)NC([R3])C(=O)NC(C)N</smiles><smiles>CCCCC</smiles><smiles>[R]C(=C=O)NC(=O)C([R])N</smiles><smiles>[13CH3]C(=O)C(=O)O</smiles><smiles>[13CH]C(=O)C(=O)O</smiles><smiles>[R2]C(=C=O)NC(=O)C([R8])N</smiles><smiles>[R7]C(N)C(=O)NC([R2])C(=O)N([R3])[O-]</smiles><smiles>[Y][Y2]C(C(=O)N([R3])C)[N+](=O)C([R1])N</smiles><smiles></smiles><smiles>[R3]NCC[Y6]1nc(C([R])N)oc1=O</smiles>

Scheme 3 
Table 1. CID of anions derived from hippurylglycine

\begin{tabular}{|c|c|c|c|c|c|c|}
\hline \multirow{2}{*}{$\begin{array}{l}\text { fragment } \\
\qquad m / z\end{array}$} & \multicolumn{2}{|c|}{$m / z 235$} & \multicolumn{2}{|c|}{$m / z 191$} & \multicolumn{2}{|c|}{$m / z$} \\
\hline & $20 \mathrm{eV}$ & $25 \mathrm{eV}$ & $20 \mathrm{eV}$ & $25 \mathrm{eV}$ & $20 \mathrm{eV}$ & $25 \mathrm{eV}$ \\
\hline 217 & 1.3 & 2.0 & & & & \\
\hline 191 & 100 & 47.7 & & & & \\
\hline 173 & 5.7 & 6.3 & 9.5 & 5.7 & & \\
\hline 171 & & 1.7 & 1.7 & 4.9 & & \\
\hline 160 & 91.6 & 100 & 100 & 98.0 & & \\
\hline 158 & & 2.7 & 2.9 & 5.6 & & \\
\hline 147 & & & 4.2 & 1.5 & & \\
\hline 134 & 19.0 & 32.2 & 50.3 & 48.1 & & \\
\hline 132 & 1.5 & 4.8 & 5.6 & 15.3 & 5.6 & 3.5 \\
\hline 121 & 2.7 & 4.1 & 7.6 & 5.5 & & \\
\hline 120 & 2.1 & 4.8 & 2.3 & 8.1 & & \\
\hline 116 & 4.1 & 25.3 & 23.1 & 91.7 & 100 & 100 \\
\hline 113 & 26.6 & 52.6 & 73.0 & 100 & & \\
\hline 103 & & & 37.7 & 55.3 & & \\
\hline 85 & 2.7 & 7.6 & 10.7 & 20.3 & & \\
\hline 77 & 0.9 & 3.4 & 4.9 & 18.6 & 0.8 & 3.5 \\
\hline 74 & 35.0 & 45.6 & & & & \\
\hline
\end{tabular}

ada). In the $\mathrm{MS}^{3}$ experiments, CID in the interface region produced the fragment ion of interest which was mass-selected by the first quadrupole mass analyzer (Q) and underwent collisional activation in the quadrupole collision cell (q) with the ionic fragmen- tation products being analyzed by the time-of-flight analyzer.

With the single quadrupole instrument, ionization was by electrospray with the sample, at micromolar concentration in 1:1 $\mathrm{CH}_{3} \mathrm{CN} / 1 \%$ aqueous $\mathrm{NH}_{3}$, being
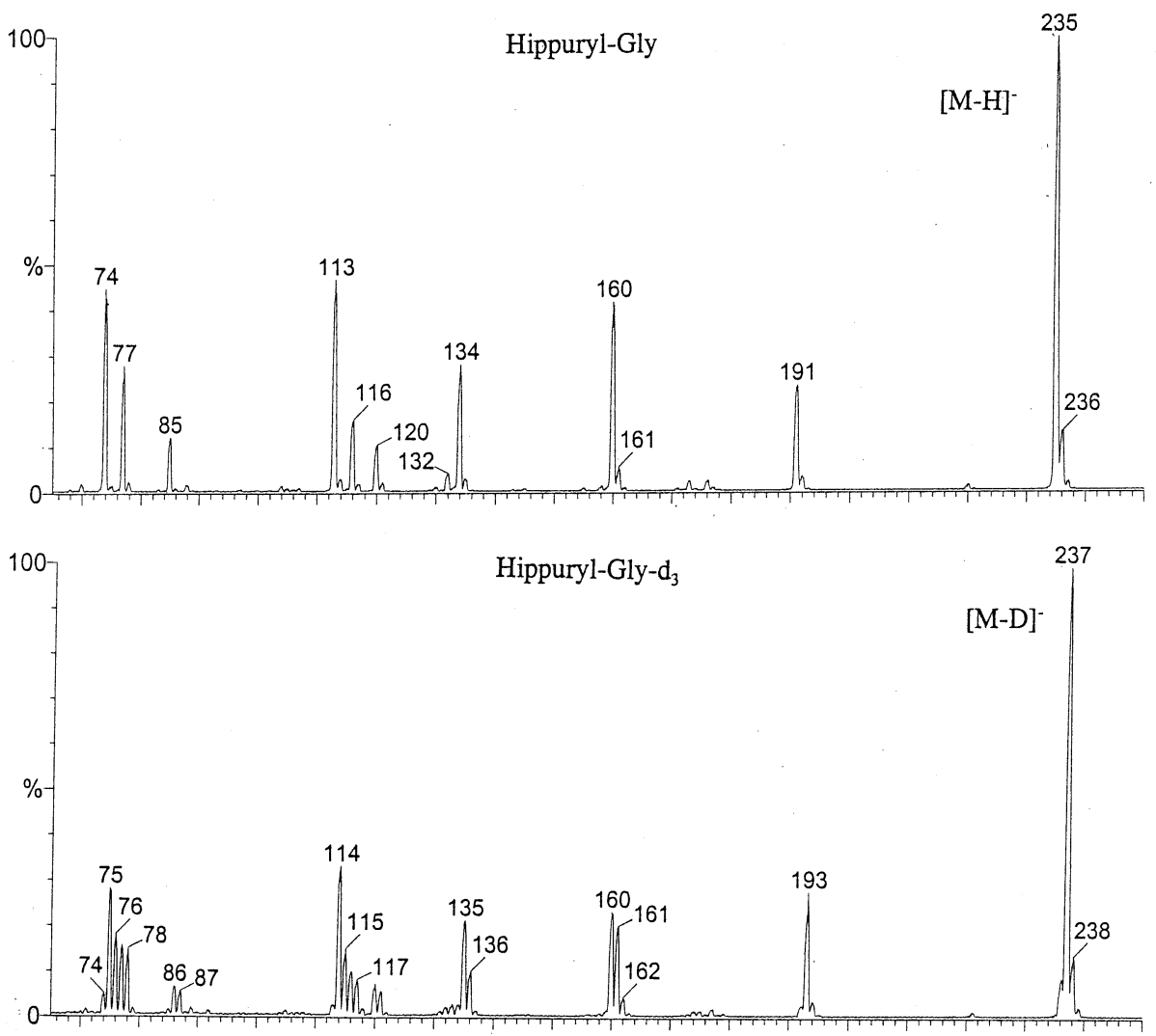

Figure 1. Comparison of the CID mass spectrum of deprotonated hippurylglycine with that of the $[\mathrm{M}-\mathrm{D}]^{-}$ion of hippurylglycine- $\mathrm{d}_{3}$. Cone voltage $50 \mathrm{~V}$. 


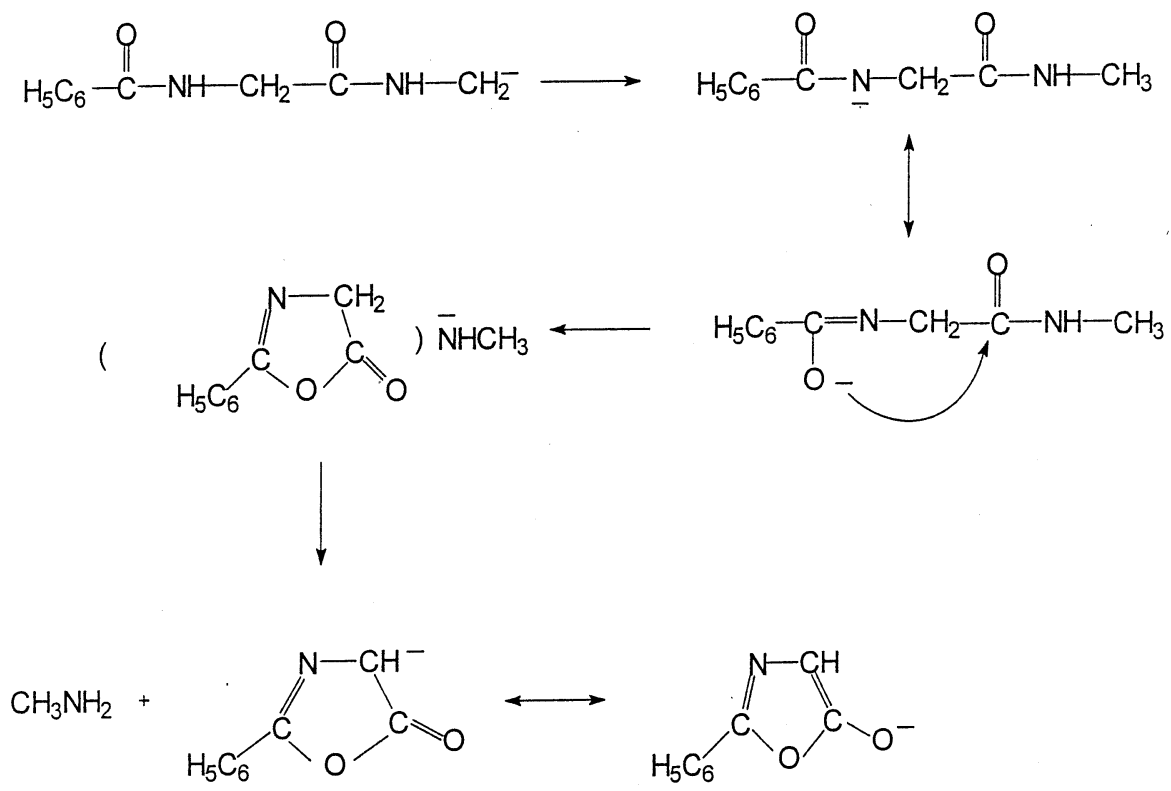

Scheme 4

introduced into the source at a flow rate of $30 \mu \mathrm{L} \mathrm{min}^{-1}$. The electrospray needle was held at -2.5 to $3.0 \mathrm{kV}$. Nitrogen, produced by a Whatman model 75-72 $\mathrm{N}_{2}$ generator (Whatman Inc, Haverhill, MA) was used as both nebulizing gas and drying gas. By using 1:1 $\mathrm{CD}_{3} \mathrm{CN} / 1 \% \mathrm{ND}_{3}$ in $\mathrm{D}_{2} \mathrm{O}$ as the electrospray solvent, the labile hydrogens were exchanged for deuterium and the $[\mathrm{M}-\mathrm{D}]^{-}$ion was formed in the ionization process. Under these conditions no evidence was seen for backexchange in the interface region although such backexchange was observed when dry air was used as nebulizing and drying gas. Ionization was also by electrospray with the QqTOF instrument with the sample, in 1:1 $\mathrm{CH}_{3} \mathrm{OH} / 1 \%$ aqueous $\mathrm{NH}_{3}$, being introduced into the source at a flow rate of $80 \mu \mathrm{L} \mathrm{min}{ }^{-1}$. Dry air was used as nebulizing and drying gas with $\mathrm{N}_{2}$ being used as the collision gas under multiple collision conditions.

All peptide samples were obtained from BACHEM Biosciences (King of Prussia, PA). $\mathrm{CD}_{3} \mathrm{CN}$ (99.8 atom\% D) and $\mathrm{D}_{2} \mathrm{O}(99.9$ atom $\%$ D) were obtained from Cambridge Isotope Laboratories (Andover, MA) while $\mathrm{ND}_{4} \mathrm{OD}\left(26 \%\right.$ in $\mathrm{D}_{2} \mathrm{O},>99$ atom $\%$ D) was obtained from CDN Isotopes (Pointe Claire, Quebec, Canada).

\section{Results and Discussion}

Table 1 records the CID mass spectra at two collision energies of deprotonated hippurylglycine (N-benzoylglycylglycine) as well as the CID mass spectra of the fragment ions of $m / z 191\left(\left[\mathrm{M}-\mathrm{H}-\mathrm{CO}_{2}\right]^{-}\right)$and $m / z 160$ as obtained on the QqTOF instrument. Figure 1 compares the CID mass spectrum obtained by cone-voltage CID of the deprotonated species with that of the [M -
$\mathrm{D}^{-}$ion of the peptide in which the labile hydrogens were exchanged for deuterium.

Of particular interest in the present context is the

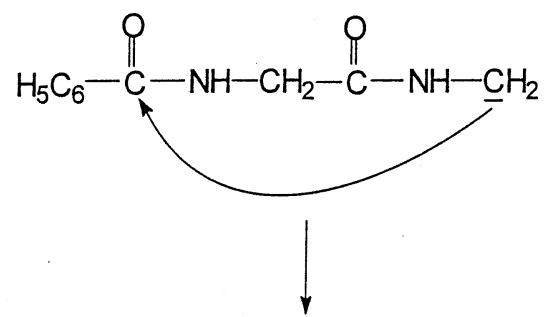<smiles>O=C1CNC(=O)CN1</smiles>

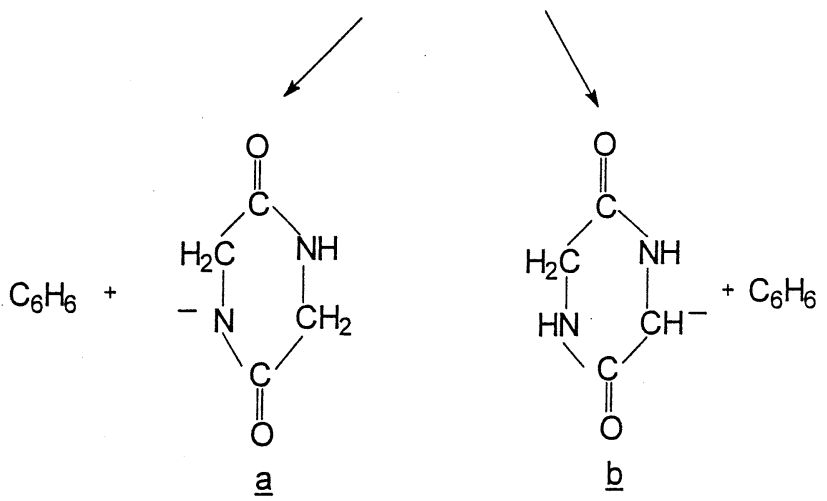

Scheme 5 


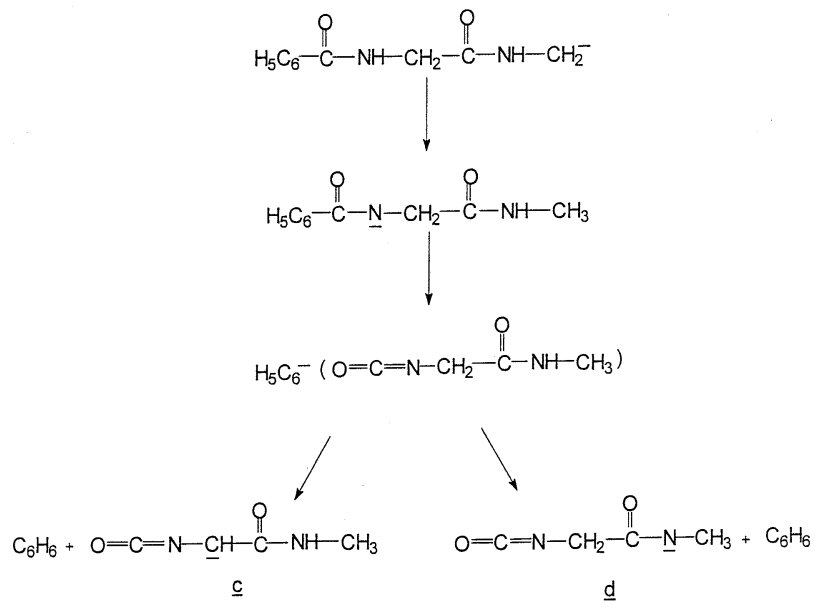

Scheme 6

fragment ion of $\mathrm{m} / \mathrm{z} 160$. The $\mathrm{MS}^{3}$ experiments show that this fragment ion originates mainly by loss of $31 \mathrm{Da}$ $\left(\mathrm{CH}_{3} \mathrm{NH}_{2}\right)$ from the $\mathrm{m} / \mathrm{z} 191\left(\left[\mathrm{M}-\mathrm{H}-\mathrm{CO}_{2}\right]^{-}\right)$ion, a fragmentation reaction recently elucidated [21], although we cannot rule out the possibility of direct formation from the $[\mathrm{M}-\mathrm{H}]^{-}(\mathrm{m} / \mathrm{z} 235)$ ion by loss of neutral glycine as a minor pathway. The MS ${ }^{3}$ experiments also show that the major fragmentation mode of the $\mathrm{m} / \mathrm{z} 160$ ion involves loss of $\mathrm{CO}_{2}$ to give the fragment ion of $\mathrm{m} / \mathrm{z} 116$. Clearly, in the $\mathrm{m} / \mathrm{z} 160$ ion the two oxygens have become bonded to the same carbon. This observation is most readily rationalized in terms of formation of a deprotonated oxazolone (2-phenyl-5oxazolone) by elimination of methylamine from the $[\mathrm{M}$
$\left.-\mathrm{H}-\mathrm{CO}_{2}\right]^{-}$as illustrated in Scheme 4. Elimination of $\mathrm{CO}_{2}$ is at first surprising since it involves the breaking of a $\mathrm{C}-\mathrm{C}$ bond which has at least partial double bond character; the driving force for the elimination of $\mathrm{CO}_{2}$ is undoubtedly the high thermochemical stability of $\mathrm{CO}_{2}$ although the structure of the $\mathrm{m} / \mathrm{z} 116$ ion is unclear. The pathway to the deprotonated oxazolone outlined in Scheme 4 predicts that no labile hydrogens should be retained by the fragment; however, as shown in Figure 1 , there is appreciable retention of one labile hydrogen in the fragment. At the same time we note that there is appreciable incorporation of one labile hydrogen in the phenyl anion $(\mathrm{m} / \mathrm{z} 77)$ indicating that there is interchange of labile hydrogens and a phenyl hydrogen although the mechanism and timing are not clear. That the deuterium incorporation in the phenyl ring does not occur in the liquid phase follows from the clean shift of the deprotonated species to $\mathrm{m} / \mathrm{z} 137$ (Figure 1) in the deuterated solvent.

A second major fragment ion arising from the $\mathrm{m} / \mathrm{z}$ 191 ion is seen at $\mathrm{m} / \mathrm{z} 113$, corresponding to elimination of neutral benzene from the $\left[\mathrm{M}-\mathrm{H}-\mathrm{CO}_{2}\right]^{-}$ion. $\mathrm{A}$ plausible mechanism for benzene elimination is shown in Scheme 5 involving formation of an intermediate complex of a phenyl anion and a neutral diketopiperazine (cyclo-GlyGly). Within this complex, proton abstraction may occur either from the nitrogen or the carbon to form the isomeric deprotonated diketopiperazines $\mathbf{a}$ and $\mathbf{b}$. Our ab initio calculations [23] indicate that the $\mathbf{C}$-deprotonated diketopiperazine $\mathbf{b}$ is ca. 10 kcal mol ${ }^{-1}$ higher in energy than the $\mathrm{N}$-deprotonated species a, but that both the $\mathrm{N}-\mathrm{H}$ and $\mathrm{C}-\mathrm{H}$ bonds in the

Table 2. CID of anions derived from hippurylglycylglycine

\begin{tabular}{|c|c|c|c|c|c|c|}
\hline \multirow{2}{*}{$\begin{array}{c}\text { fragment } \\
\mathrm{m} / \mathrm{z}\end{array}$} & \multicolumn{2}{|c|}{$m / z 292$} & \multicolumn{2}{|c|}{$m / z 248$} & \multicolumn{2}{|c|}{$m / z 191$} \\
\hline & $20 \mathrm{eV}$ & $25 \mathrm{eV}$ & $20 \mathrm{eV}$ & $25 \mathrm{eV}$ & $20 \mathrm{eV}$ & $25 \mathrm{eV}$ \\
\hline 274 & 4.2 & & & & & \\
\hline 248 & 97.6 & 29.8 & & & & \\
\hline 230 & 11.6 & 5.7 & 18.1 & 8.1 & & \\
\hline 217 & 42.3 & 8.5 & & & & \\
\hline 191 & 100 & 100 & 100 & 100 & & \\
\hline 178 & 8.5 & 3.6 & & & & \\
\hline 177 & 5.6 & 6.2 & & 2.2 & & \\
\hline 173 & 7.1 & 6.3 & & & 8.7 & 9.8 \\
\hline 160 & 53.6 & 51.0 & 45.8 & 41.0 & 100 & 88.4 \\
\hline 158 & & 2.8 & & 1.6 & 2.8 & 6.3 \\
\hline 134 & 8.5 & 1.4 & 6.8 & 10.0 & 49.9 & 55.4 \\
\hline 132 & & & & & 5.7 & 15.5 \\
\hline 131 & 19.5 & 13.4 & & & & \\
\hline 121 & & & & & 7.6 & 7.0 \\
\hline 120 & 54.7 & 59.9 & 16.8 & 28.0 & 66.4 & 64.3 \\
\hline 116 & & 2.1 & & & 25.7 & 84.7 \\
\hline 113 & 22.6 & 28.0 & 20.2 & 22.4 & 70.8 & 100 \\
\hline 103 & & & & & 16.1 & 14.1 \\
\hline 87 & 6.3 & 11.2 & 4.1 & 8.4 & & \\
\hline 85 & & & & & 10.4 & 26.1 \\
\hline 77 & & & & & 7.6 & 18.3 \\
\hline 74 & 22.8 & 20.3 & & & & \\
\hline 70 & & & & & 5.2 & 7.3 \\
\hline
\end{tabular}




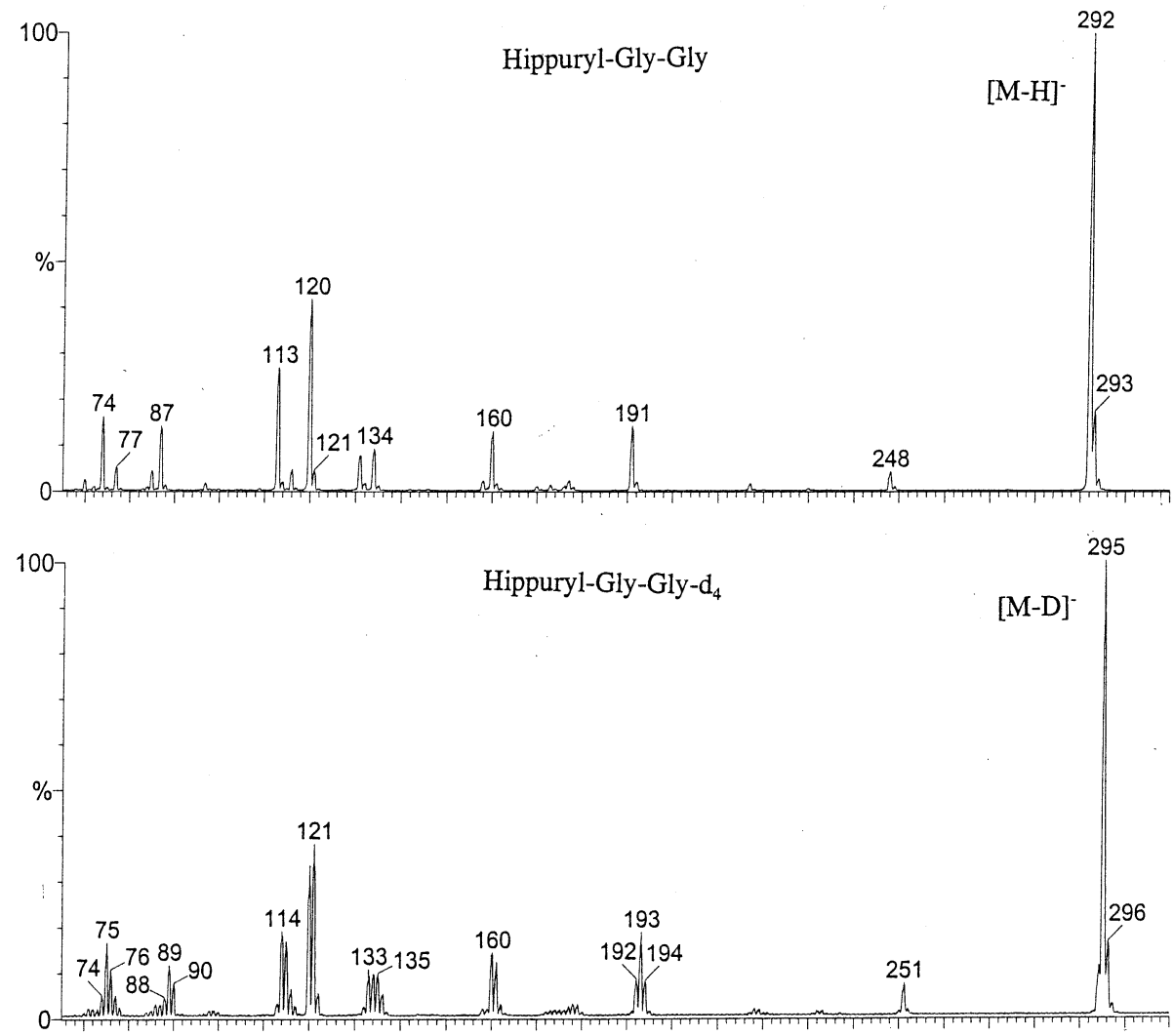

Figure 2. Comparison of the CID mass spectrum of deprotonated hippurylglycylglycine with that of the $[\mathrm{M}-\mathrm{D}]^{-}$ion of hippurylglycylglycine- $\mathrm{d}_{4}$. Cone voltage $50 \mathrm{~V}$.

diketopiperazine are considerably more acidic than the $\mathrm{C}-\mathrm{H}$ bond in benzene making proton abstraction from either position exothermic. An alternative pathway to $m / z$ 113, outlined in Scheme 6, involves proton abstraction from the $\mathrm{N}$-terminal amide position leading to the phenyl anion/neutral complex shown. $\mathrm{Ab}$ initio calculations [23] show that the isocyanato neutral in the complex is only 6-7 kcal mol ${ }^{-1}$ higher in energy than the diketopiperazine of Scheme 5 and that the anion $\mathbf{d}$ derived by $\mathrm{N}-\mathrm{H}$ deprotonation has essentially the same energy as the $\mathrm{N}$-deprotonated diketopiperazine a. The anion c is $17.5 \mathrm{kcal} \mathrm{mol}^{-1}$ higher in energy than a or $\mathbf{d}$ but proton abstraction from this position by the phenyl anion remains exothermic [23]. From the spectra of Figure 1 it is clear that the $\mathrm{m} / \mathrm{z} 113$ ion incorporates one and, to some extent, two labile hydrogens. Given the apparent interchange of a phenyl hydrogen with a labile hydrogen this observation provides no significant information. Unfortunately, we were unable to carry out $\mathrm{MS}^{3}$ experiments on the $\mathrm{m} / \mathrm{z} 113$ fragment ion because of a strong and continual background signal at $m / z 113\left(\left[\mathrm{CF}_{3} \mathrm{COO}\right]^{-}\right)$in the QqTOF instrument. At the present time we are not able to clearly elucidate the pathway(s) to $\mathrm{m} / \mathrm{z} 113$ and further studies of related compounds are under way.

Two further fragment ions of note in the fragmentation of deprotonated hippurylglycine are the $\mathrm{y}_{1}$ ion, deprotonated glycine, at $\mathrm{m} / \mathrm{z} 74$ and the ion signal at $\mathrm{m} / \mathrm{z}$ $134\left(\left[\mathrm{C}_{6} \mathrm{H}_{5} \mathrm{C}(=\mathrm{O}) \mathrm{NHCH}_{2}\right]^{-}\right)$which presumably arises by loss of $\mathrm{CH}_{2}=\mathrm{NH}+\mathrm{CO}$ from the $\left[\mathrm{M}-\mathrm{H}-\mathrm{CO}_{2}\right]^{-}$ $(\mathrm{m} / \mathrm{z}$ 191) ion.

The $m / z 160$ and $m / z 113$ ions are prominent in the CID mass spectrum of deprotonated hippurylglycylglycine (N-benzoyl-triglycine). $\mathrm{MS}^{2}$ and $\mathrm{MS}^{3} \mathrm{CID}$ mass spectra are presented in Table 2 while, in Figure 2, the CID mass spectrum of the $[\mathrm{M}-\mathrm{H}]^{-}$ion is compared with that of the $[\mathrm{M}-\mathrm{D}]^{-}$ion of the peptide in which the labile hydrogens have been exchanged for deuterium. The $m / z 160$ ion gave a CID mass spectrum (not shown) very similar to that of the $m / z 160$ ion derived from deprotonated hippurylglycine (Table 1 ) with the main fragmentation mode being loss of $\mathrm{CO}_{2}$ consistent with a deprotonated 2-phenyl-5-oxazolone structure. The CID mass spectra of Table 2 show that a major route to the $\mathrm{m} / \mathrm{z} 160$ ion involves the reaction sequence illustrated in Scheme 7 although some formation of $\mathrm{m} / \mathrm{z} 160$ directly from $[\mathrm{M}-\mathrm{H}]^{-}$by elimination of neutral diglycine cannot be discounted. It is also possible that the $\mathrm{m} / \mathrm{z} 160$ product may arise directly from the $\left[\mathrm{M}-\mathrm{H}-\mathrm{CO}_{2}\right]^{-}$by elimination of neutral glycine methylamide. Other ions of interest in the fragmentation of $[\mathrm{M}-\mathrm{H}]^{-}$are the $\mathrm{y}_{1}$ ion at $\mathrm{m} / \mathrm{z} 74$ and the $\mathrm{y}_{2}$ ion at $\mathrm{m} / \mathrm{z} 131$. The $\mathrm{m} / \mathrm{z}$ 191 ion is predicted in Scheme 7 to have the same structure as the $\mathrm{m} / \mathrm{z} 191\left(\left[\mathrm{M}-\mathrm{H}-\mathrm{CO}_{2}\right]^{-}\right)$ion 


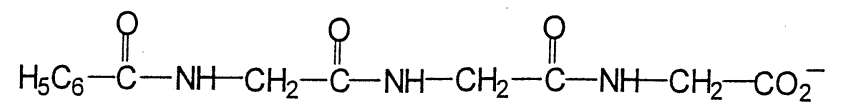

$\mathrm{m} / \mathrm{z} 292$<smiles>[Y]C(C)C(=O)[O-]</smiles><smiles>[CH2-]C(=O)NCC(=O)NCC(=O)NCC(C)(C)C</smiles>

$\mathrm{m} / \mathrm{z} 248$

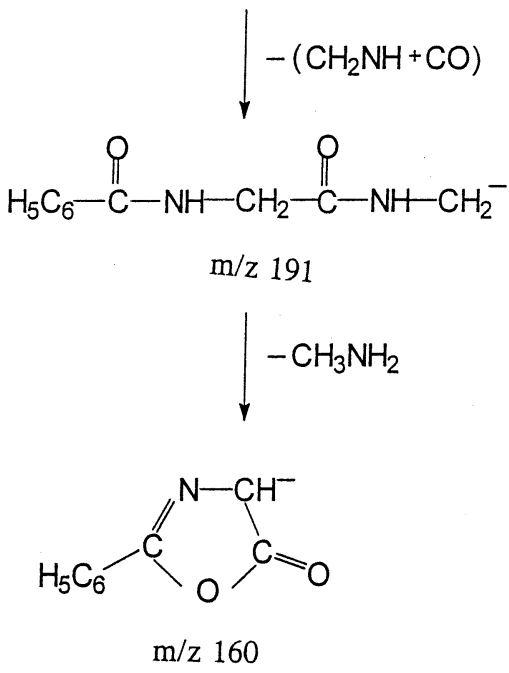

Scheme 7

derived from hippurylglycine and, indeed, the two ion show very similar CID mass spectra with the exception that the former ion shows (Table 2) a much more pronounced signal at $\mathrm{m} / \mathrm{z} 120\left(\left[\mathrm{C}_{6} \mathrm{H}_{5} \mathrm{CONH}\right]^{-}\right)$; the reasons for this difference are not obvious.

Deprotonated hippurylphenylalanine (N-benzoylglycylphenylalanine) also shows a fragment ion of $m / z 160$ (Table 3 and Figure 3). This ion shows (Table 3 ) the characteristic loss of $\mathrm{CO}_{2}$ indicating the deprotonated oxazolone structure. However, CID of the [M $\left.-\mathrm{H}-\mathrm{CO}_{2}\right]^{-}(\mathrm{m} / z$ 281) ion does not lead to the deprotonated oxazolone by the pathway analogous to Scheme 4 involving elimination of 2-phenylethyl amine from the $[\mathrm{M}-\mathrm{H}]^{-}$ion. Rather the $[\mathrm{M}-\mathrm{H}-$ $\left.\mathrm{CO}_{2}\right]^{-}$ion $(\mathrm{m} / \mathrm{z} 281)$ fragments essentially completely by elimination of $104 \mathrm{Da}\left(\mathrm{C}_{8} \mathrm{H}_{8}\right.$, styrene?) to give $\mathrm{m} / \mathrm{z}$ 177 which also is the base peak in the CID mass spectrum of $[\mathrm{M}-\mathrm{H}]^{-}$. Presumably, elimination of $\mathrm{C}_{8} \mathrm{H}_{8}$ from the $\left[\mathrm{M}-\mathrm{H}-\mathrm{CO}_{2}\right]^{-}$ion is a lower energy fragmentation route than elimination of 2-phenylethyl amine. A fragment ion of $\mathrm{m} / \mathrm{z} 177$ also may arise by direct loss of cinnamic acid from the $[\mathrm{M}-\mathrm{H}]^{-}$ion, a fragmentation reaction previously elucidated [34] for deprotonated peptides containing C-terminal phenylalanine. The $\mathrm{m} / \mathrm{z} 177$ ion fragments, in part, by
Table 3. CID of anions derived from hippurylphenylalanine ( $20 \mathrm{eV}$ collision energy)

\begin{tabular}{ccccc}
\hline $\begin{array}{c}\text { fragment } \\
m / z\end{array}$ & $m / z$ 325 & $m / z 281$ & $m / z 177$ & $m / z 160$ \\
\hline \hline 307 & 0.8 & & & \\
281 & 26.9 & & & \\
264 & 2.1 & & & \\
203 & 1.1 & & & \\
189 & 1.4 & & & \\
177 & 100 & 100 & & \\
164 & 52.5 & & & \\
160 & 28.6 & 1.7 & 100 & \\
159 & 5.2 & 3.4 & 77.3 & \\
147 & 7.2 & & & \\
134 & 1.4 & 0.8 & 42.7 & \\
132 & & & 4.9 & 4.3 \\
120 & 1.6 & & & \\
116 & & & 32.6 & 100 \\
99 & & & 49.4 & \\
77 & & & 7.7 & 1.3 \\
71 & & & 7.4 & \\
\hline
\end{tabular}

elimination of $\mathrm{NH}_{3}$ to give deprotonated 2-phenyl-5oxazolone $(\mathrm{m} / \mathrm{z} 160)$; the labeling results (Figure 3) show that in this case the deprotonated oxazolone contains no labile hydrogens. The apparent pathway to $\mathrm{m} / \mathrm{z} 160$ is outlined in Scheme 8. The $\mathrm{m} / \mathrm{z} 177$ ion also fragments, in part, by elimination of $\mathrm{H}_{2} \mathrm{O}$, a reaction previously observed [34] for ions formed by elimination of cinnamic acid from deprotonated peptides containing C-terminal phenylalanine. Deprotonated phenylalanine ( $\mathrm{y}_{1}$ ion) also is observed at $\mathrm{m} / \mathrm{z}$ 164.

The formation of deprotonated oxazolones is not limited to N-benzoyl derivatives. Fragmentation of the $[\mathrm{M}-\mathrm{H}]^{-}$ion derived from N-acetyl-Ala-Ala-OH shows (Table 4 and Figure 4) $\mathrm{y}_{1}(\mathrm{~m} / \mathrm{z} 88)$ and $\mathrm{m} / \mathrm{z} 115$ $\left(\left[\mathrm{M}-\mathrm{H}-\mathrm{CH}_{2} \mathrm{CO}-\mathrm{CO}_{2}\right]^{-}\right)$as the major fragment ions but of particular interest is the relatively weak signal at $\mathrm{m} / \mathrm{z} 112$ which appears to arise by elimination of neutral alanine from the $[\mathrm{M}-\mathrm{H}]^{-}$ion. CID of the $\mathrm{m} / \mathrm{z} 112$ ion showed (Table 4) loss of $\mathrm{CH}_{3}(\mathrm{~m} / \mathrm{z}$ 97) and loss of $\mathrm{CO}(\mathrm{m} / \mathrm{z} 84)$ but also a significant signal at $\mathrm{m} / z 68$ corresponding to elimination of $\mathrm{CO}_{2}$ which we take to be characteristic of a deprotonated oxazolone structure. Whereas elimination of $\mathrm{CO}$ forms the base peak in the fragmentation of $\mathrm{m} / \mathrm{z} 112$ it is only a minor peak in the fragmentation of the $m / z 160$ ions derived from the benzoyl derivatives. It appears that the phenyl group stabilizes the fragment ion resulting from $\mathrm{CO}_{2}$ loss to a much greater extent than does the methyl group. Exchange of the labile hydrogens for deuterium (Figure 4) shows that the major part of the ion signal does not incorporate labile hydrogens as expected. Note again that CID of the $\left[\mathrm{M}-\mathrm{H}-\mathrm{CO}_{2}\right]^{-}$ ion $(m / z 157)$ did not result in formation of $m / z 112$ by a pathway analogous to Scheme 3 ; it is not clear why this is so. The MS $^{3}$ experiments show that the $m / z 115$ ion arises by two pathways, initial loss of ketene 


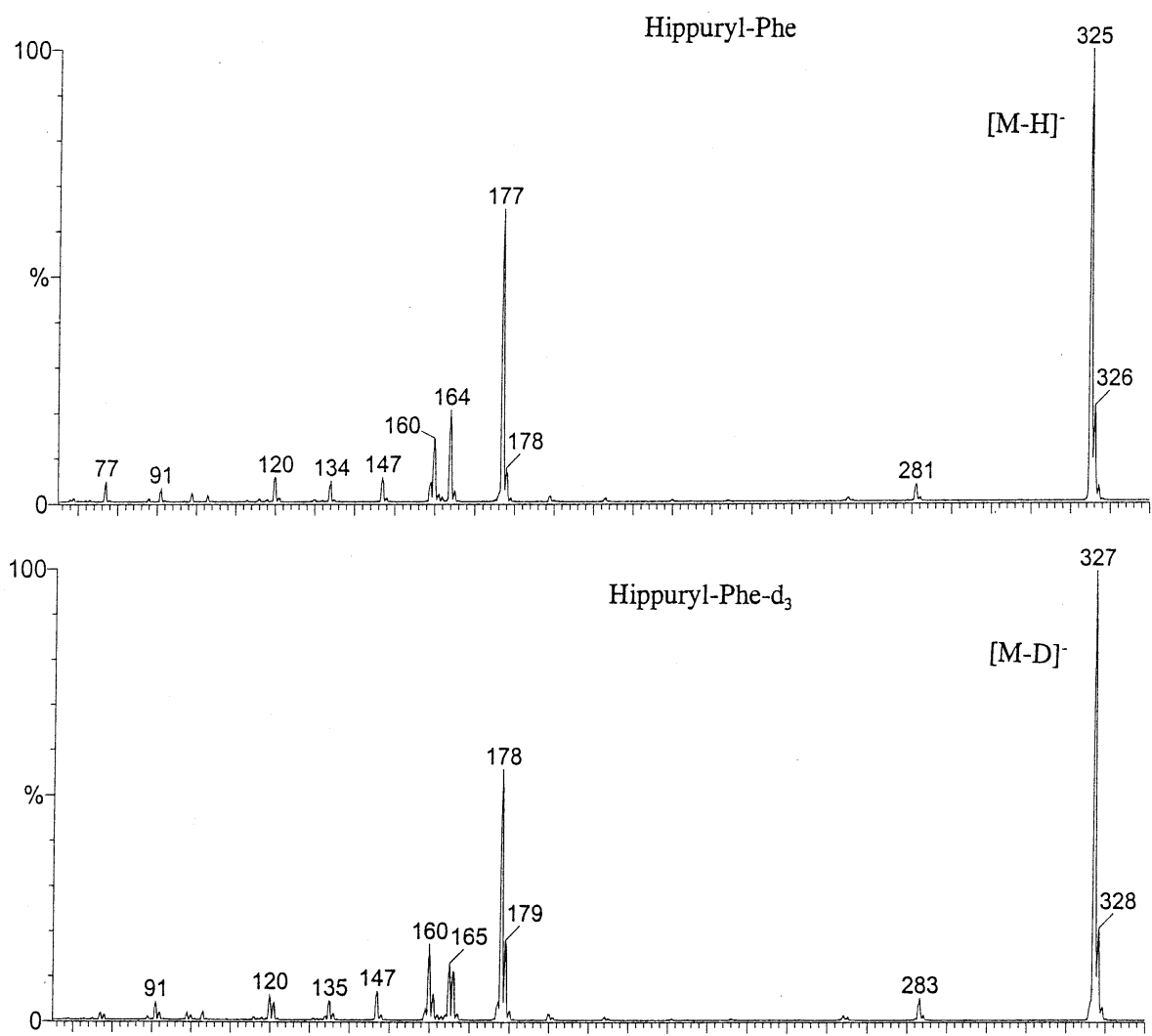

Figure 3. Comparison of the CID mass spectrum of deprotonated hippurylphenylalanine with that of the $[\mathrm{M}-\mathrm{D}]^{-}$ion of hippurylphenylalanine- $\mathrm{d}_{3}$. Cone voltage $50 \mathrm{~V}$.

followed by loss of $\mathrm{CO}_{2}$ and initial loss of $\mathrm{CO}_{2}$ followed by loss of ketene. The major part of the $\mathrm{m} / \mathrm{z}$ 115 signal incorporates two labile hydrogens as expected.

\section{Conclusions}

The present work has shown that deprotonated Nbenzoyl (i.e., hippuryl) peptides fragment, in part, to

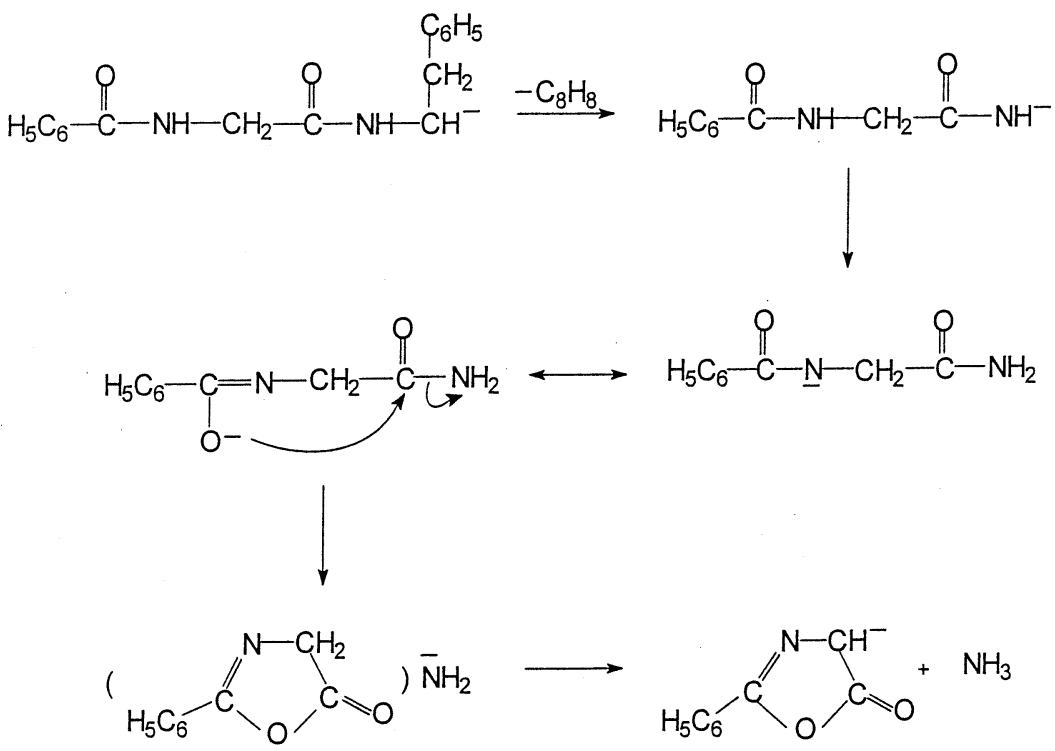

Scheme 8 
Table 4. CID of anions derived from deprotonated Nacetylalanylalanine ( $20 \mathrm{eV}$ collision energy)

\begin{tabular}{rrrrr}
\hline $\begin{array}{c}\text { fragment } \\
m / z\end{array}$ & $m / z 201$ & $m / z 159$ & $m / z 157$ & $m / z 112$ \\
\hline \hline 159 & 17.4 & & & \\
157 & 5.6 & & & \\
141 & & 2.0 & & \\
129 & 2.1 & & & \\
117 & & 3.2 & & \\
115 & 69.3 & 100 & 100 & \\
112 & 12.5 & & & \\
99 & & 3.6 & & \\
98 & & 21.2 & & 10.7 \\
97 & & & & \\
89 & & & & \\
88 & 100 & 63.5 & & \\
87 & & 12.3 & & \\
84 & & & & \\
72 & & 8.2 & & \\
70 & & 3.7 & & \\
68 & & & & \\
58 & & & & \\
\hline
\end{tabular}

form an ion of $\mathrm{m} / \mathrm{z} 160$ which has been identified as deprotonated 2-phenyl-5-oxazolone on the basis of the dominant loss of $\mathrm{CO}_{2}$ upon collisional activation. The pathways to this product are varied. For deprotonated hippurylglycine the $\mathrm{m} / \mathrm{z} 160$ product originates largely by elimination of $\mathrm{CH}_{3} \mathrm{NH}_{2}$ from the [M
- $\left.\mathrm{H}-\mathrm{CO}_{2}\right]^{-}(\mathrm{m} / \mathrm{z}$ 191) ion, a reaction pathway recently elucidated [21], although we cannot rule out some formation directly from the $[\mathrm{M}-\mathrm{H}]^{-}$ion. For deprotonated hippurylglycylglycine a major pathway involves loss of $57 \mathrm{Da}$ (probably $\mathrm{CH}_{2}=\mathrm{NH}+\mathrm{CO}$ ) from $\left[\mathrm{M}-\mathrm{H}-\mathrm{CO}_{2}\right]^{-}$to produce an ion of $\mathrm{m} / \mathrm{z} 191$ which subsequently eliminates $\mathrm{CH}_{3} \mathrm{NH}_{2}$, as observed for deprotonated hippurylglycine. However, we cannot rule out the possibility that some of the oxazolone product originated directly from the $\left[\mathrm{M}-\mathrm{H}-\mathrm{CO}_{2}\right]^{-}$ ion (involving nominal elimination of glycine methylamide) or, possibly, directly from the [M $\mathrm{H}]^{-}$ion. For deprotonated hippurylphenylalanine the $\left[\mathrm{M}-\mathrm{H}-\mathrm{CO}_{2}\right]^{-}$ion preferentially eliminates a neutral of $104 \mathrm{Da}$ (styrene?) to form an ion that is nominally deprotonated N-benzoylglycinamide; this species subsequently eliminates ammonia to form the deprotonated oxazolone. Again, direct formation from the $[\mathrm{M}-\mathrm{H}]^{-}$ion remains a possible second pathway.

Formation of deprotonated oxazolones is not limited to benzoyl derivatives since deprotonated $\mathrm{N}$-acetylalanylalanine, upon fragmentation, produces an ion of $\mathrm{m} / \mathrm{z}$ 112 which we have identified as deprotonated 2,4dimethyl-5-oxazolone from the characteristic loss of $\mathrm{CO}_{2}$.

Finally, we note that protonated hippuryl peptides, such as hippurylglycine and hippurylphenylalanine,
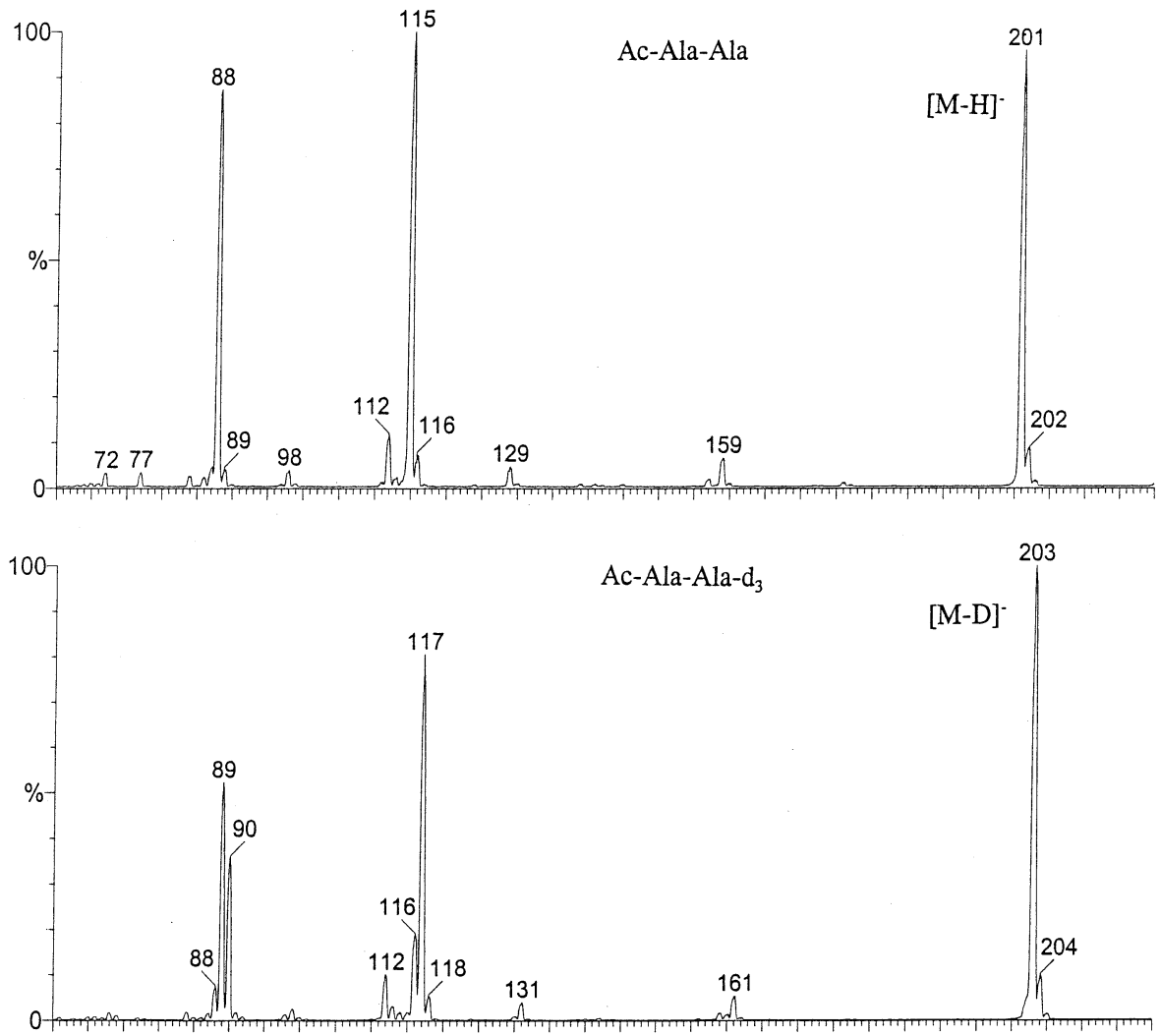

Figure 4. Comparison of the CID mass spectrum of deprotonated acetylalanylalanine with that of the $[\mathrm{M}-\mathrm{D}]^{-}$ion of acetylalanylalanine- $\mathrm{d}_{3}$. Cone voltage $50 \mathrm{~V}$. 
upon fragmentation form an ion of $m / z 162$ which has been identified as protonated 2-phenyl-5-oxazolone [7, 9]. Indeed, the tendency of peptides in the positive ion mode to form product ions containing five-membered rings has been discussed in detail [35]. It appears that there may be a similar tendency in the negative ion mode.

\section{Acknowledgments}

This work was supported by the Natural Sciences and Engineering Research Council (Canada) through a research grant to AGH and through an equipment grant to the Department of Chemistry for the purchase of the QStar.

\section{References}

1. Roepstorff, P.; Fohlman, J. Proposal for a Common Nomenclature for Sequence Ions in Mass Spectra of Peptides. Biomed. Mass Spectrom. 1984, 11, 601.

2. Biemann, K. Contribution of Mass Spectrometry to Peptide and Protein Structure. Biomed. Env. Mass Spectrom. 1988, 16, 99.

3. Biemann, K. Sequencing of Peptides by Tandem Mass Spectrometry and High-Energy Collision-Induced Dissociation. Methods Enzymol. 1990, 193, 455.

4. Papayannopoulos, I. A. The Interpretation of Collision-Induced Dissociation Tandem Mass Spectra of Peptides. Mass Spectrom. Rev. 1995, 14, 49.

5. Mueller, D. R.; Eckersley, M.; Richter, W. Hydrogen Transfer in Formation of " $Y+2$ " Sequence Ions from Protonated Peptides. Org. Mass Spectrom. 1988, 23, 217.

6. Cordero, M. M.; Houser, J. J.; Wesdemiotis, C. The Neutral Products Formed During Backbone Fragmentation of Protonated Peptides in Tandem Mass Spectrometry. Anal. Chem. 1993, 65, 1594.

7. Yalcin, T.; Khouw, C.; Csizmadia, I. G.; Peterson, M. R.; Harrison, A. G. Why are B Ions Stable Species in Peptide Mass Spectra? J. Am. Soc. Mass Spectrom. 1995, 6, 1165.

8. Yalcin, T.; Csizmadia, I. G.; Peterson, M. R.; Harrison, A. G. The Structure and Fragmentation of $\mathrm{B}_{n}(n \geq 3)$ in Peptide Mass Spectra. J. Am. Soc. Mass Spectrom. 1996, 7, 293.

9. Nold, M. J.; Wesdemiotis, C.; Yalcin, T.; Harrison, A. G. Amide Bond Dissociation in Protonated Peptides. Structures of the N-Terminal Ionic and Neutral Fragments. Int. J. Mass Spectrom. Ion Processes 1997, 164, 137.

10. Paizs, B.; Lendvay, G.; Vékey, K.; Suhai, S. Formation of $b_{2}^{+}$ Ions from Protonated Peptides: An ab Initio Study. Rapid Commun. Mass Spectrom. 1999, 13, 525.

11. Harrison, A. G.; Csizmadia, I. G.; Tang, T.-H. Structures and Fragmentation of $b_{2}$ Ions in Peptide Mass Spectra. J. Am. Soc. Mass Spectrom. 2000, 11, 427.

12. Rodriquez, C. F.; Shoeib, T.; Chu, I. K.; Siu, K. W. M.; Hopkinson, A. C. Comparison Between Protonation, Lithiation, and Argentination of 5-Oxazolones: A Study of a Key Intermediate in Gas-Phase Peptide Sequencing. J. Phys. Chem. A 2000, 104, 5335.

13. Farrugia, J. M.; O’Hair, R. A. J.; Reid, G. E. Do All b $b_{2}$ Ions have Oxazolone Structures? Mass Spectrometry and ab Initio Studies on Protonated N-Acyl Amino Acid Methyl Ester Model Systems. Int. J. Mass Spectrom. 2001, 210/211, 71
14. Vaisar, T.; Urban, J. Gas-Phase Fragmentation of Mono-NMethylated Peptides. Analogy with Solution-Phase Acid-Catalyzed Hydrolysis. J. Mass Spectrom. 1998, 33, 505.

15. Kulik, W.; Heerma, W. Fast Atom Bombardment Tandem Mass Spectrometry for Amino Acid Determination in Tripeptides. Biomed. Env. Mass Spectrom. 1989, 18, 9.

16. van Setten, D.; Kulik, W.; Heerma, W. Isomeric Tripeptides: A Study on Structure-Spectrum Relationship. Biomed. Env. Mass Spectrom. 1990, 19, 475.

17. Eckersley, M.; Bowie, J. H.; Hayes, R. N. Collision-Induced Dissociation of Deprotonated Peptides: Dipeptides and Tripeptides with Hydrogen and Alkyl $\alpha$-Groups. Org. Mass Spectrom. 1989, 24, 597.

18. Waugh, R. J.; Bowie, J. H. A Review of the Collision Induced Dissociations of Deprotonated Dipeptides and Tripeptides. An Aid to Structure Determination. Rapid Commun. Mass Spectrom. 1994, 8, 169.

19. Bowie, J. H.; Brinkworth, C. S.; Dua, S. Collision Induced Fragmentations of the $[\mathrm{M}-\mathrm{H}]^{-}$Parent Anions of Underivatized Peptides. An Aid to Structure Determination and Some Unusual Negative Ion Cleavages. Mass Spectrom. Rev. 2002, 21, 87.

20. Harrison, A. G. Sequence-Specific Fragmentation of Deprotonated Peptides Containing H or Alkyl Side Chains. J. Am. Soc. Mass Spectrom. 2001, 12, 1.

21. Harrison, A. G.; Siu, K. W. M.; El Aribi, H. Amide Bond Cleavage in Deprotonated Tripeptides: A Newly Discovered Pathway to " $\mathrm{b}_{2}$ Ions. Rapid Commun. Mass Spectrom. 2003, 17, 869.

22. Chass, G. A.; Marai, C. N. J.; Harrison, A. G.; Csizmadia, I. G. Fragmentation Reactions of $\mathrm{a}_{2}$ Ions Derived from Deprotonated Dipeptides-A Synergy Between Experiment and Theory. J. Phys. Chem. A 2002, 106, 9695.

23. Chass, G. A., Marai, C. N. J., Csizmadia, I. G., Harrison, A. G. A Hartree-Fock, MP2 and DFT Computational Study of the Structures and Energies of $" \mathrm{~b}_{2}$ Ions Derived from Deprotonated Peptides. A Comparison of Method and Basis Set Used on Relative Product Stabilities. J. Molec. Struct. (THEOCHEM), in press.

24. Loo, J. A.; Udseth, H. R.; Smith, R. D. Collisional Effects on the Charge Distribution of Ions From Large Molecules Formed by Electrospray-Ionization Mass Spectrometry. Rapid Commun. Mass Spectrom. 1988, 2, 207.

25. Bruins, A. P. ESI Source Design and Dynamic Range Considerations. In Electrospray Mass Spectrometry: Fundamentals, Instrumentation, and Applications; Cole, R. B., Ed.; Wiley: New York, 1997, p 107.

26. Voyksner, T. D.; Pack, T. Investigation of CollisionalActivation Decomposition Processes and Spectra in the Transport Region of an Electrospray Single-Quadrupole Mass Spectrometer. Rapid Commun. Mass Spectrom. 1991, 5, 263.

27. Collette, C.; DePauw, E. Calibration of the Internal Energy of Ions Produced by Electrospray. Rapid Commun. Mass Spectrom. 1998, 12, 165.

28. Collette, C.; Drahos, L.; DePauw, E.; Vékey, K. Comparison of the Internal Energy Distribution of Ions Produced by Different Electrospray Sources. Rapid Commun. Mass Spectrom. 1998, 12, 1673.

29. Harrison, A. G. Energy-Resolved Mass Spectrometry. A Comparison of Quadrupole Cell and Cone Voltage Collision-Induced Dissociation. Rapid Commun. Mass Spectrom. 1999, 13, 1663

30. van Dongen, W. D.; van Wijk, J. I. T.; Green, B. M.; Heerma, W.; Haverkamp, J. Comparison Between Collision Induced Dissociation of Electrosprayed Protonated Peptides in the 
Up-Front Region and in a Low-Energy Collision Cell. Rapid Commun. Mass Spectrom 1999, 13, 1712.

31. Harrison, A. G. Fragmentation Reactions of Alkylphenyl Ammonium Ions. J. Mass Spectrom. 1999, 34, 1253.

32. Makowiecki, J.; Tolonen, A.; Uusitalo, J.; Jalonen, J. Cone Voltage and Collision Cell Collision-Induced Dissociation of Triphenylethylenes of Pharmaceutical Interest. Rapid Commun. Mass Spectrom. 2001, 15, 1506.

33. McLuckey, S. A.; Cooks, R. G. Angle- and Energy-Resolved Fragmentation from Tandem Mass Spectrometry. In Tandem
Mass Spectrometry; McLafferty, F. W., Ed.; Wiley: New York, 1983, p 203.

34. Harrison, A. G. Effect of Phenylalanine on the Fragmentation of Deprotonated Peptides. J. Am. Soc. Mass Spectrom. 2002, 13, 1242.

35. Schlosser, A.; Lehmann, W. D. Five-Membered Ring Formation in Unimolecular Reactions of Peptides: A Key Structural Element Controlling Low-Energy Collision-Induced Dissociation of Peptides. J. Mass Spectrom. 2000, 35, 1382. 